\title{
Conservation and sustainable resource use in the Hadejia-Jama'are Valley, Nigeria
}

\author{
William M. Adams and David H. L. Thomas
}

\begin{abstract}
Sustainable development is increasingly being seen as a legitimate, and locally critical, element in wildlife conservation. However, relatively few studies of projects attempt to combine conservation and development goals. The Hadejia-Nguru Wetland Conservation Project in Nigeria grew out of a concern for wildife (particularly wetland birds), but has expanded to address issues of environmental sustainability and economic development at both the local and the regional scale. This paper assesses the achievements of the project's approach.
\end{abstract}

\section{Conservation and sustainable development}

Eltringham (1994) asked 'Can wildlife pay its way?' and by posing that question he marked a major shift in the way in which we understand and conceive of conservation. During the last decade, ideas about wildlife conservation based on the designation of protected areas have increasingly given way to attempts to integrate human needs and conservation objectives at the local scale and particularly to a new focus on people and parks (McNeely and Miller, 1984; Brandon and Wells, 1992; Wells and Brandon, 1992). These new ideas have grown from increasing concern about the failings of conventional exclusionist approaches to conservation, particularly in Africa, and recognition by conservationists of the validity of developmental claims by poor rural communities (e.g. Adams and McShane, 1992). The patterns of 'fortress' conservation are no longer seen to be wholly acceptable, or effective. In recent years there has been increased awareness both of the problems that can be caused to local people by the establishment of protected areas and the impossibility of achieving conservation objectives without addressing socio-economic needs.

New approaches to protected areas include the notion of zonation and buffer zones, for example in Biosphere Reserves (Batisse, 1982). However, Blower (1984) commented that local people are likely to oppose the establishment of parks unless 'strenuous and imaginative efforts are made from the start to involve them in planning and development of the park', and to see that they benefit from any employment generated (p. 725). The creation of new economic opportunities in a buffer zone around a national park may take human pressure off the national park itself. Development here is being used as a means of winning over local opposition to conservation objectives, the carrot that balances the more conventional sticks, such as antipoaching and land-use control measures.

Changes in international conservation thinking about protected-area policy in recent decades have been deeply influenced by wider debates about sustainable development (Adams, 1990). This notion of sustainable development has become the chief means by which conservationists have sought to theorize a new relationship between local development and wildlife conservation. The idea that there was some form of development that is 'sustainable', in the sense that it maximized human welfare while avoiding environmental costs, emerged at the 1972 United Nations Conference on the Human Environment in Stockholm, and was in due course the central concept in the World Conservation Strategy (WCS; IUCN, WWF and UNEP, 1980), in the report of the World Commission on Environment and Development (Brundtland, 
1987), in the WCS's successor, Caring for the Earth (IUCN, 1991), and at the UN Conference on Environment and Development in Rio in 1992. Sustainable development has become a common phrase on the lips of politicians, development bureaucrats and commentators (Redclift, 1987; Adams, 1990). The promotion of sustainable development formed one of IUCN's seven programme areas for the period 1985-87. The original plan to revise the WCS every 3 years gave way to progressive adaptation as national conservation strategies were produced under IUCN guidance (McCormick, 1989). A major revision was discussed at the IUCN General Assembly in Perth in 1990.

Conservation is increasingly being seen in terms of its role in sustainable development, and development (particularly meeting the needs of local people) is now widely seen as a necessary condition of effective conservation. None the less, there are relatively few case studies of attempts to combine conservation and sustainable development. This paper offers such a case study. It discusses the practical experience of the Hadejia-Nguru Wetlands Conservation Project (HNWCP) in northern Nigeria, which has tried to implement some of these new ideas about the integration of conservation objectives and the needs of local communities, using the concepts and framework of sustainable development. Both authors have been involved with the HNWCP since 1987, in different capacities and to different degrees, and in describing the problems the project has faced we are describing to a large extent the limitations of our own insights and understanding*. Our comments are therefore explicitly self-critical, and intended to be constructive.

\footnotetext{
* W.M.A. has carried out research in the Hadejia-Jama'are floodplain since 1987 and worked with the HNWCP for short periods on various occasions, D.H.L.T. was employed by IUCN as technical consultant to the HNWCP between 1989 and 1992 and has conducted research in the area since that time. The views expressed here are the authors' own and do not represent those of any organization.
}

\section{Conservation in the Hadejia-Nguru Wetlands, Nigeria}

The Hadejia and Jama'are rivers drain northeastwards through Kano, Bauchi, Jigawa, Yobe and Borno States in north-east Nigeria. They join near the town of Hadejia before moving on to flow into Lake Chad as the Komadugu Yobe. Between Hadejia and Gashua, some $100 \mathrm{~km}$ downstream, the rivers flow through an extensive area of low sand dunes, between 10 and $30 \mathrm{~m}$ in height, and several $\mathrm{km}$ in length (Figures 1 and 2). These cause a confused drainage pattern and a range of wetland environments, including seasonally and permanently flooded land mixed with dry farmland, has developed that has been labelled the Hadejia-Nguru Wetlands (Figure 1). The rainfall of the HadejiaJama'are basin ranges from $1300 \mathrm{~mm}$ per year in the south-west to under $500 \mathrm{~mm}$ in the north-east at Gashua. Annual rainfall is variable, with poor rains between 1972 and 1978 and between 1980 and 1987 (Hollis et al., 1993a). Rainfall is concentrated in a single wet season (c. May-September), and river flow is highly seasonal. Almost 80 per cent of total runoff in the Hadejia and Jama'are occurs in August and September. The human population of the floodplain is large (up to 1 million people), with Hausa, Bedde, Fulani and Kanuri communities. There is a sizeable economy based on rainy season and dry season agriculture, fishing and grazing (Barbier et al., 1991).

The rich wildlife of the Hadejia-Nguru Wetlands has long been recognized. Anecdotal reports by wildfowlers were confirmed in the 1970s (Elgood, 1977), and a more detailed study demonstrated the national and international importance of the area for Palaearctic and Afrotropical birds (Ash and Sharland, 1986). The area is part of a system of wetlands in the Sahel that provides important passage and wintering grounds for substantial numbers of Palaearctic migrant birds, particularly waterfowl, as well as important habitat for Afrotropical species (Stowe and Coulthard, 1990). The area is internationally important for the ferruginous duck Aythya nyroca, supporting over 1 per cent of the Western Palaearctic 
Figure 1. Location of the Hadejia-Jama' are Wetlands.

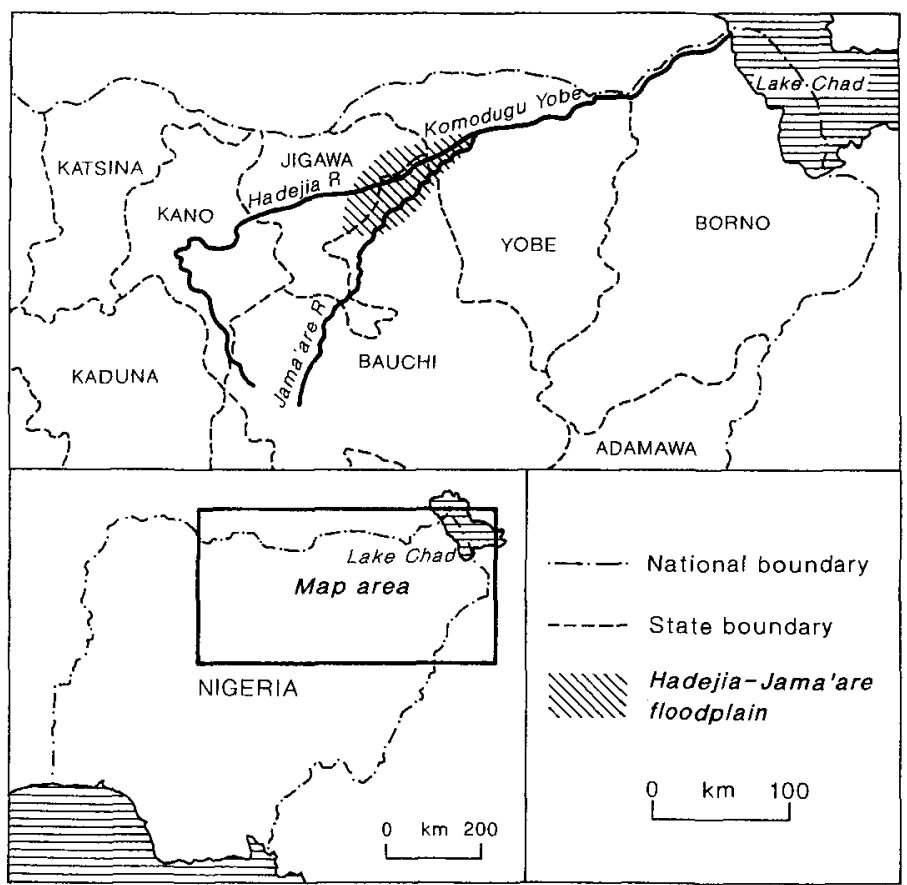

resource use could be allowed to evolve over time in response to environmental, demographic and socio-economic change.

In a second protected-area initiative, the Borno State Government declared a bird sanctuary in a deeply flooded oxbow lake at the village of Dagonna in 1989 (Figure 2). This lake holds water late into the dry season, and is an important site for birds, particularly comb ducks. The bird sanctuary was inaugurated in February 1989 on the occasion of a visit by the President of the World Wide Fund for Nature, but there is now little to show of the sanctuary. Game guards were appointed by the Borno State Ministry, but were not paid regularly or adequately equipped so there has been little incentive to do the unpopular job of patrolling the area. The site had no effective protection and the limited infrastructure (road, bird-watching hide, patrol huts, signboards and commemorative plaque) is in disrepair. Dagonna villagers have complained of poaching by outsiders (people from neighbouring villages and gangs from further afield), and of their use of poisons to kill birds.

The HNWCP was established in 1987 with the signing of a memorandum of understand- 


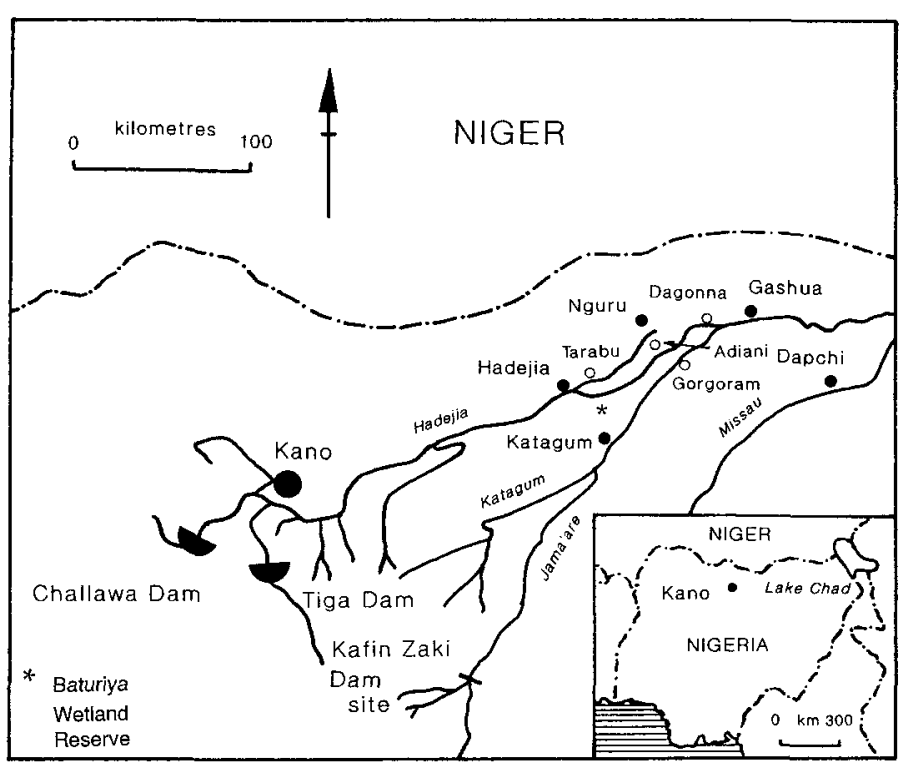

Figure 2. The Hadejia-Jama'are Wetlands and major dams in the basin. ing on the 'Lake Chad Wetland Project' between the Federal Government, the Royal Society for the Protection of Birds (RSPB) and the International Council for Bird Preservation (ICBP, now BirdLife International). The HNWCP aims to promote conservation and sustainable development of the HadejiaJama' are floodplain. Initially it was sponsored by the Nigerian Conservation Foundation (NCF), International Union for Conservation of Nature and Natural Resources (IUCN), RSPB and BirdLife International, and field activities started in January 1987. The promotion of sustainable use in the floodplain has taken place on two scales. The first involved the creation of community-level development 'microprojects'. The second addressed a much larger-scale critique of management of the water resources of the whole basin, and in particular the unsustainable development represented by dam construction and irrigation upstream of the wetlands.

In August 1991 the Chad Basin National Park was created (Federal Government Decree 36 1991, Section 2), based on two existing Forest Reserves (Gorgoram and Zurgun Baderi) plus two other areas (the ChingurmiDuguma Game Reserve and the Bulatura Oasis). The new park faces a considerable range of problems. First, it is a fragmented multi-location park (with some pieces over $200 \mathrm{~km}$ apart); second, none of the fragments has been surveyed and their boundaries are not securely identified, either on maps or on the ground; third, all pieces are remote and in the wet season mutually inaccessible; and fourth, it contains very large numbers of people: farmers, fishermen and pastoralists. No census has been carried out, but given the large number of people living in the wetlands as a whole, it would be surprising if the wetland forest fragments within the park did not hold at least 50,000 people in the dry season when Fulani graziers move into the area. Most forms of human use are prohibited in the park unless covered by a permit issued by the park's Director. Thus it is illegal to hunt, capture, destroy or collect an animal; to uproot, burn or otherwise damage a plant, to kindle a fire or to turn or cultivate the soil or obstruct the course of a stream (Decree 36, 1991, Section 27). The park thus makes illegal the basis of subsistence for a great many people (hunting, grazing, farming and fishing), yet quite apart from the welfare implications, the removal of this number of people from the park is impossible politically and also financially (unless government compensation rates for land expropriation are ignored). The limitations of this approach to conservation are obvious. 


\section{Conservation and local development}

When the HNWCP was established, it rapidly became clear that bird conservation was not an objective with which people in the wetlands readily identified. The idea of conserving wildlife was met with indifference or even opposition rather than public support. Birds were seen to provide a source of food, and as pests: cormorants, storks and herons eat fish caught in traps or nets; flocks of ruff Philomachus pugnax damage rice crops; pied crows Corvus albus eat beans and red-billed quelea Quelea quelea attack millet, sorghum and irrigated wheat. Thinking about how to approach conservation in the wetlands was therefore forced to evolve, and the project's activities were broadened to try to embrace human needs and the notion of sustainable use of the wetland's resources. In 1989, the HNWCP started to develop a programme of 'microprojects'. The hope was that very smallscale development initiatives could begin to meet needs of local people in an environmentally benign (and therefore 'sustainable') way and could, in the process, create positive environmental benefits, particularly for wildlife conservation.

The first microproject was the construction of a fishpond at Dagonna, Borno State, designed explicitly to compensate for the loss of fishing rights in the oxbow lake included in the bird sanctuary (Thomas, 1994). The lake is an important fishing ground for the people of Dagonna, many of whom are full-time fishermen with little or no alternative dry-season occupation. An associated hamlet, Dagonna Sabon Gari, consists entirely of migrant fishermen from Sokoto in north-west Nigeria, and the oxbow lake is the site of an annual fishing festival that attracts hundreds of fishermen from across northern Nigeria. It was planned that the new artificial fishpond would be filled by natural river flooding every year and stocked with wild-caught fish that would be fed until they reached harvestable size. It was hoped that the pond would act as a pilot project for a 'blue revolution' that might have widespread applicability in the wetlands.

The fishpond offered an innovative and in- genious solution to the local socio-economic impacts of an imposed conservation policy. In technical terms it was successful (in that the new pond, built cheaply in part of a cut-off river channel) filled as planned. However, the project was less successful in socio-economic terms (Thomas, 1992b). Analysis of the current catch from the oxbow showed that the predicted production of the fishpond would not compensate for lost fish production in the oxbow lake sanctuary. A switch to fish culture is unlikely to occur unless returns exceed those of fish capture, for example if the natural fish population becomes severely degraded. There is no evidence that this was happening at Dagonna, where the capture fishery was still buoyant, and attractive as an economic activity. The ineffective ban on fishing in the oxbow lake did not provide a sufficient incentive for fishermen to make the cultural and economic transition from fish capture to fish culture. The planning of the Dagonna fishpond also disregarded the social importance of the fishing festival.

The pond represented a completely different approach to fish production, and the extent and significance of the social and cultural change required to make it successful was also underestimated. Unlike capture fishing (Thomas, 1995a), fish culture requires a high level of co-operation, collective labour and trust. In the capture fishery of the oxbow lake, returns to labour were quite high and there was a clear relationship between the inputs made by individual fishermen (catch-effort, experience and investment in gear) and their returns. By contrast, fishpond production requires continuous inputs of labour over a long period (to catch fingerlings and feed them) before production is obtained. A community fishpond represents a very different (and less individualistic) approach to work and benefits from that of the capture fishery that it was supposed to replace. It demands voluntary contributions of time and labour, and a social structure that allocates work and benefits in a way that is both seen to be reasonable and effective. In the Dagonna fishpond, it was planned that fingerlings would be provided by individual fishermen, and that the number 
of fish and other inputs provided would be recorded so that returns to each participant could be allocated. In practice, the literate and numerate members of the community kept no records, and the fishermen had little faith in a committee's ability to monitor inputs or distribute benefits accordingly. For this reason, the response of fishermen to the new project was poor, and the pond was understocked (Thomas, 1994).

The project was also founded on a simplistic understanding of local resource management institutions. It was assumed that there were likely to be 'traditional' or 'indigenous' management systems in the area that (while probably partly destroyed by modern development pressures) could be resurrected and used as the basis for new approaches to resource use and microprojects. For example, it was expected that the fisheries in each village would be controlled by a sarkin ruwa ('chief of water' in Hausa). However, a survey of 30 wetland communities showed that only two of them had a sarkin ruwa with any authority to control fishing activity (Jimoh, 1989). In part this is because of the influence of State Fishery Officers and state regulations. Although these government officials are confined to towns by lack of transport, lack local knowledge and are largely ineffective, their very existence significantly weakens the power of local resource controllers. Research on fisheries resource tenure and control by Thomas (1995a, b) revealed the weakness of these institutions. In one village surveyed, it was reported that the sarkin ruwa had obtained his title through a payment to the village head and not on the basis of competence in fishing or a recognized position of leadership among other fishermen (Thomas, 1994). This suggests that even "village-level management' might leave much to be desired, both in terms of equity and perhaps technical competence.

The Dagonna fishpond provided valuable experience, but was not repeated. Subsequent initiatives to promote sustainable development were not linked to protected areas but sought to identify independent opportunities to develop income-enhancing projects, which would have more broadly defined benefits in terms of environmental conservation. These projects included work on beekeeping, tree nurseries, duck rearing, donkey traction and rice farming (Thomas, 1990, 1992b; Thomas and Abubakar, 1992). None of these was entirely straightforward. One problem related simply to the way in which the conservatism of indigenous resource managers can inhibit dissemination of new technologies. A microproject in the village of Adiani involved experimentation by two practising beekeepers with the new technology of top-bar beehives. Hives are kept in a forest reserve adjacent to the village, and it was hoped that widespread adoption of the new hives would provide an economic incentive for the preservation of the reserve. The first hive to be harvested was a great success, but a significant constraint on adoption by other beekeepers emerged. A man called the mai zuma (literally 'master of bees') controls who may and may not keep bees, and how they should work. Two other beekeepers in the village wanted to use the top-bar hive but would not do so without permission of the mai zuma, whose magic potions are the key to safe beekeeping (bees are closely associated with certain spirits). Thus, despite the technical success of the demonstration project, the new technology remained restricted to a select few (Thomas, 1992b).

In a number of projects local perceptions of needs did not always accord with the preconceptions of project planners. In surveys, communities tend to list better roads, bridges and culverts, better medical facilities, better water supplies and petrol pumps for dry-season irrigation as their top priorities. These have little potential to make a direct contribution to wildlife conservation. Furthermore, the HNWCP has lacked the resources to help with most of them, either because of limitations of funds or expertise. On the other hand, the portfolio of projects that can be offered may not be high priorities with communities. Thus the shortage of trees for fuelwood was widely recognized as a problem (almost all fuelwood being bought in from outside). However, there was not always enthusiasm for the idea of a tree nursery. In one village, where a fruit-tree 
nursery was eventually established, trees had been removed from fields because of the threat of roosting quelea. The lack of fuelwood was seen as less serious than both the threat from quelea and the need for a better water supply.

Not only did local priorities for investment differ in some instances from those anticipated by the project, but so too could their ideas about social organization. The microprojects were initially built on Western notions of social equality and co-operation. Efforts were made to ensure that benefits were distributed as widely as possible. While cultural norms in different ethnic groups within the wetlands embody a strong element of social concern, this is very different from (and much more hierarchical than) this Western model, and there was considerable potential for a mismatch of the two systems of values. Interestingly, there are few truly co-operative ventures in the wetlands. Major community infrastructure projects (wells, clinics, roads) will see the mobilization of most of the able-bodied men in the community, but co-operative action in ventures intended to generate direct economic benefits is more rare. Most economic activities (fishing, farming, trading) are carried out on an individual or household basis. There is little support for the idea of co-operative action for economic activity nor is the institutional context helpful to formal co-operative development. The fishpond at Dagonna demanded co-operative action, and the lack of this greatly limited its effectiveness.

After the first year, emphasis on the microproject programme shifted to more individualistic projects. For example, a communal tree nursery had been started in Tarabu, but suffered rapid erosion of support because it was located in the village head's compound. It was replaced by a project growing tree seedlings in individual compounds. This won greater commitment, although it suffered technical and administrative problems. For example, it was found that providing extension services and visits to 80 small household nurseries was not feasible, so that many farmers made error's that led to failure and discouragement. Out of 3610 pots distributed in the village and sown, only 234 trees were produced (Thomas, 1990). Microprojects with community development and conservation objectives began to be seen primarily as demonstration projects designed to explore and illustrate new technology (e.g. Thomas 1992; Thomas and Abubakar, 1992). This approach made it hard not to involve a disproportionate number of the wealthier and more powerful people in the community, partly because they are looked to as leaders (and may demand to continue in that role) and partly because they may be more willing or able to innovate. It is not possible (even if it were desirable) to bypass the village head. In practice, the HNWCP simply became much more selective about which villages to work in, trying to develop projects only in villages where the head was sympathetic to the project's aims and to the needs and interest of his villagers. None the less, if microprojects are to be demonstrations for wider adoption, the implications of working in less benign environments will have to be tackled eventually.

The key to the long-term impact of the microproject programme is whether the technologies and ideas introduced are interesting enough to participants to be replicated elsewhere within the wetland. There are many constraints on this dissemination. In particular, it cannot be assumed that state government ministries will be either welcome or effective participants in this process. Problems of lack of transportation severely constrain the effectiveness of these agencies. Furthermore, their involvement may be unwelcome, as it was in Dagonna where villagers feared that they would have to pay a commission for any input to the fishpond project (Thomas, 1994). In practice the Borno State Ministry was left out simply because it had no transport to reach the village (Thomas 1992a).

The move of the HNWCP into development creates problems associated with the risk of loss of distinctiveness, and of increasing distance from the core concerns of species conservation. The HNWCP is not the only agency in the area seeking 'environmentally sound' community-level development projects. In particular, the European Community's North East Arid Zone Development Programme 
(NEAZDP) has also been operating in the wetlands within Yobe state, with a vastly larger budget. It has recognized the value of the HNWCP's work, and replicated some of its projects over wider areas, along with others. In Dagonna village, for example, it has reequipped the clinic, repaired and refurnished the school, is setting up a community bank and millet-processing plant, and plans to improve the access road and help with a new borehole. This is all admirable, and it is based on a very similar view of the links between environmental degradation and development needs, and a similar view of community-level planning to that used by the HNWCP. However, the level of investment completely swamps the HNWCP's microproject programme and does not draw explicit links between microprojects and wildlife conservation. It also raises all kinds of expectations about levels of investment that the HNWCP will never be able to fulfil.

\section{Conservation and sustainability at the regional scale}

This account has focused on some of the difficulties encountered with the development of the microprojects programme. These criticisms need to be seen in context, for many of the projects were successful, and the programme has undoubtedly had a considerable value in demonstrating ways in which sustainable development might be achieved at a local scale. However, the significance of all such local attempts to integrate conservation and development are dwarfed by the question of sustainability at a much larger scale. Both the economy and ecology of the Hadejia-Jama'are floodplain are threatened by dams and water abstraction for irrigation upstream within the Hadejia and Jama'are river basins, particularly in low-rainfall years (Hollis et al., 1993a; Carter, 1995; Thompson and Hollis, 1995). Lack of floodwater presents a threat to both wildlife conservation interests and economic activities such as fishing and agriculture that transcends any conflicts that might exist between them (Kimmage and Adams, 1992;
Thomas, 1995b). It is questionable whether sustainable development (by whatever definition) is possible in the wetlands if upstream projects continue to be developed without consideration of downstream needs. Clearly both wildlife and the local economy demanded a focus on sustainability on a large scale as well.

Construction of the Tiga Dam (upstream of the wetlands on the Kano River) and the drought of the 1970s and 1980s brought significant environmental degradation (Stock, 1978; Hollis et al., 1993a), and both the Tiga and the second dam built in the headwaters of the Hadejia River at Challawa have altered the timing and size of flood flows (Hollis et al., 1993a; Figure 2). The timing, extent and duration of flooding in the Hadejia-Jama'are floodplain depend on both the seasonal flood in the rivers and the status of groundwater beneath, which are themselves closely connected. The extent of flooding declined, from over $3000 \mathrm{sq} \mathrm{km}$ in 1950 to $1000-2000 \mathrm{sq} \mathrm{km}$ in the $1970 \mathrm{~s}$. Only $700 \mathrm{sq} \mathrm{km}$ were flooded in 1987 (Adams and Hollis, 1989) and $525 \mathrm{sq} \mathrm{km}$ in 1992 following completion of Challawa Gorge Dam (Hollis et al., 1993a). This reduction is due to drought, water storage in the reservoirs behind Tiga Dam and Challawa Gorge Dam and abstraction of irrigation water. The effect has been increased since the dam at Challawa and the barrage at Hadejia, which is part of the Hadejia Valley Project, were completed. Further abstraction of surface or groundwater for irrigation upstream will increase evaporation of water that could otherwise support rice farming, irrigation, fishing and other activities in the Hadejia-Jama'are floodplain. Reduced river floods will also threaten downstream users, particularly rice farmers and irrigators below Gashua, whose demands for water are leading to renewed interest in an attempt to channelize or bypass the complex channel system between Hadejia and Gashua (Hollis et al., 1993a). In addition, there is increasing awareness of the probable importance of river flooding in recharging of groundwater well beyond the boundaries of the floodplain, suggesting that reduced flooding could have economic 
and welfare implications over a wide area (Hollis et al., 1993b).

The HNWCP has attempted to demonstrate the nature and value of economic activities in the wetlands (Barbier et al,, 1991; Kimmage and Adams, 1992). Demonstration of the economic importance of the Hadejia-Jama'are floodplain provides perhaps the only argument for the maintenance of flood flows into and within the floodplain that might have the power to influence government planners. In the past, the lack of formal development investment (i.e. identifiable 'projects' run by government agencies) in the floodplain has allowed decision-makers to assume that the area is relatively unimportant economically. This is far from the case: it supports very large numbers of people and produces large amounts of food.

This line of critique is fairly effective, partly because the economic shortcomings of the Nigerian large-scale irrigation schemes are relatively obvious (e.g. Adams, 1991). It has been possible to demonstrate that there is a high degree of common ground between the interests of conservation (focused on the maintenance of wetland flooding for migratory birds) and those of peasant farmers and fishermen interested in the maintenance of floods for their livelihoods. In this sense, wildlife conservation is promoting the interests of local people, and doing so with an ideology that is fairly effective in capturing the ear of the Nigerian elite through the Nigerian Conservation Foundation.

The productivity of the wetlands depends on the annual flood. Reduction in that flood will shrink the resource base available to people and will create a gap too large to be bridged by microprojects alone. Patterns of flooding have been variable in recent years, but there have been a number of years when flooding has been very limited. Sule (1993) found that only 52 per cent of the wetland was flooded in only one of the four recent years for which data were available (1986, 1987, 1990, 1991), while only 5 per cent flooded in all four years (Hollis et al., 1993b). Extensive areas of the floodplain were left dry in the 1990 rainy season due to low rains, and flooding was par- ticularly restricted in 1992 due to the closure of the Challawa Dam. Studies in such years shows that livestock production can be much reduced, and communities report increased rates of dry-season labour emigration (Thomas, 1995b). As the resource base shrinks, that which remains is used more intensively. Fishing catch-efforts are rising and catches are falling (Thomas, 1995b). Serious conflicts over land are emerging between cultivators and pastoralists. The microprojects programme has provided evidence that the HNWCP project is interested in more than simply bird preservation, but the need now is to emphasize the larger-scale issues of regional water management.

\section{Conclusions}

Four conclusions can be drawn from this case study of conservation and sustainable use in the Hadejia-Jama'are Valley. The first is simply the enormous importance of making the link between conventional wildlife conservation, ecosystem function and human use, and particularly the recognition of the economic dimensions of biodiversity (e.g. McNeely, 1993). The integration of economic development with species and ecosystem conservation is vital. Conservation in developing countries is unlikely to be successful unless the needs of local people are met and a clear link is demonstrated between conservation aims and local economic needs. It is also true that it is hard to imagine long-term success for conservation strategies in developing countries that are not fully compatible with (and ideally directly contribute to) sustainable economic futures. Links between wildlife conservation, environmental quality and human welfare need to be extended to be made clear to local people, the government agencies responsible for environmental management and development policy, and the aid donors who fund development projects. The issue of sustainability is vital to conservation planning. If conservation is to win an effective place in the thinking of those planning the development of the tropics, concern must extend beyond the 
obvious interest in environmental sustainability to embrace social and economic sustainability.

The second conclusion from this study is that conservation needs to consider sustainability at different scales. The most obvious, although not necessarily the most important, is the local scale, where problems such as hunting, illegal forest felling or illegal fishing may have a direct impact on the integrity of protected areas. At a slightly larger scale, there is a need to integrate conservation and development around formal protected areas (for example in national park 'support zones') to meet the human needs that drive protectedarea degradation. However, not all conservation interest can be represented within protected-area systems, and the management of the wider environment will have implications both for protected areas (at risk of ecological isolation and species extinctions), and for the potential for the maintenance of natural diversity at a regional scale. The management of ecosystems in these unprotected landscapes will depend on the success with which conservation goals are built into economic development plans. Wetlands such as those in the Hadejia-Jama'are Valley demonstrate the importance of these unprotected landscapes (for wildlife and people), the potentially great common ground between conservation and the needs of people, and the need to look beyond the immediate horizon to consider the implications for both conservation and sustainability of development some long distance away, in the river basin upstream. Conservation planning needs to take account of sustainability and to do so at a range of different scales.

The third conclusion is that the work of development demands skills that are different from those required by conventional conservation projects. This point was also made by Stocking and Perkin (1992) in the context of an 'integrated conservation and development project' in the East Usambaras in Tanzania. It is social science rather than biological science that is going to be most useful in building an interface between conservation and development. Important skills are those gained from practical experience of working with communities, carrying out and interpreting socioeconomic surveys, understanding political economy, and experience of working with technicians (particularly engineers), economists and planners. Many people in conservation will be skilled in these areas already, and others will rapidly acquire skills and experience through training and field projects. In the short term, conservation organizations may well need to buy in expertise in these areas, but the kinds of insights needed cannot simply be bolted on to the outside of existing projects. Socio-economic work should be fully integrated into project planning, and not treated as a separate activity (as, regrettably, development planners still tend to treat environmental studies). New skills and new thinking may demand significant changes in the way conservation projects are conceived and organized. This work will not be cheap and, to be effective, the new approaches will have to permeate and influence ideas and action at all levels. Simply to graft a development component on to a conservation project is unlikely to be any more effective than tacking an environmental study on to the back of a development project.

Lastly, this case study makes clear that while it may be essential to seek to integrate conservation and development it is far from easy to do so. We believe that these issues are important to the future of conservation, particularly in Africa, and that practical and critical debate of past practice is essential if we are to learn, and to develop the professional skills necessary to tackle the challenges ahead. Two things are vital. First, that we are not unrealistic about the ease with which conservation and sustainable resource use can be integrated. We must be realistic about what can be achieved, and not taken in by our own wishful thinking. Second, we must be prepared to learn from our mistakes, and that means we have to discuss them professionally. Unless we do that, all the enthusiasm in the world is not going to achieve much on the ground. 


\section{References}

Adams, J.S. and McShane, T.O. 1992. The Myth of Wild Africa: Conservation without Illusion. W. W. Norton and Company, New York.

Adams, W.M. 1990. Green Development: Environment and Sustainability in the Third World. Routledge, London.

Adams W.M. 1991. Large scale irrigation in northern Nigeria: performance and ideology. Trans. Inst. Brit. Geogr. NS, 16, 287-300

Ash, J.H. and Sharland, R.E. 1986. Nigeria: Assessment of Bird Conservation Priorities. International Council for Bird Preservation, Cambridge.

Barbier, E.B., Adams, W.M. and Kimmage K. 1991. Economic Valuation of Wetland Benefits: the HadejiaJama'are Floodplain, Nigeria. LEEC Paper DP-91-02, IIED, London.

Batisse, M. 1982. The biosphere reserve: a tool for environmental conservation and management. Environmental Conservation, 9, 101-111.

Blower, J. 1984. National Parks for developing countries. In National Parks, Conservation and Development: The Role of Protected Areas in Sustaining Society (eds J. A. McNeely and K. R. Miller), pp. 722-727. Smithsonian Institute Press, Washington, DC.

Brandon, K.E. and Wells, M. 1992. Planning for people and parks: design dilemmas. World Development, 20, 557-570.

Brundtland, H. 1987. Our Common Future. Oxford University Press, Oxford (for the World Commission on Environment and Development).

Carter, R.C. 1995. A policy framework for surface water and shallow groundwater allocation, with special reference to the Komadougou Yobe River Basin, northeast Nigeria. Public Administration and Development, 15, 103-120.

Elgood, J.A. 1977. Water Resource Development in Kano State and its Effects on the Environment and Wildlife, Especially Fish and Aquatic Birds. Final Report (Hadejia Nguru Wetlands Project.

Eltringham, S.K. 1994. Can wildlife pay its way? Oryx, 28, 163-168.

Hollis, G.E., Adams, W.M. and Aminu Kano (eds). 1993a. Hydrology and Sustainable Resource Development of a Sahelian Floodplain Wetland. IUCN Wetlands Programme, Gland.

Hollis, G.E., Penson, S.J., Thompson J.R. and Sule, A.R. 1993b. Hydrology of the river basin. In Hydrology and Sustainable Resource Development of a Sahelian Floodplain Wetland (eds G. E. Hollis, W. M. Adams and Aminu Kano), pp. 19-67. IUCN Wetlands Programme, Gland.

IUCN, WWF and UNEP. 1980. The World Conservation Strategy. International Union for the
Conservation of Nature, World Wildlife Fund and United Nations Environment Programme, Gland, Switzerland.

IUCN. 1991. Caring for the Earth: a Strategy for Sustainability. International Union for Conservation of Nature, Gland, Switzerland.

Jimoh, M.A. 1989. Fuelwood-Fishery Activities in the Hadejia-Nguru Wetlands. Hadejia-Nguru Wetlands Conservation Project, Nguru, Nigeria.

Kimmage, K. and Adams, W.M. 1992. Wetland agricultural production and river basin development in the Hadejia-Jama'are Valley, Nigeria. Geographical Journal, 158, 1-12.

McCormick, J.S. 1989. Reclaiming Paradise: The Global Environmental Movement. Indiana University Press, Bloomington, Ind.

McNeely, J.A. 1993. Economic incentives for conserving biodiversity: lessons for Africa. Ambio, 22, 144-150.

McNeely, J.A. and Miller, K.R. (eds). 1984. National Parks, Conservation and Development: the Role of Protected Areas in Sustaining Society. Smithsonian Institute Press, Washington, DC.

Perennou, C. 1991. Les Récensements Internationaux d'Oiseaux d'Eau en Afrique tropicale. IWRB Publication No. 15, International Wildfowl and Wetlands Research Bureau, Slimbridge.

Redclift, M. 1987 Sustainable Development: Exploring the Contradictions. Methuen, London.

Stock, R.F. 1978. The impact of the decline of the Hadejia River floods in Hadejia Emirate. In The Aftermath of the 1972-74 Drought in Nigeria (ed. G. J. van Apeldoorn), pp. 141-146. Federal Department of Water Resources and Centre of Social and Economic Research, Ahmadu Bello University, Zaria.

Stocking, M. and Perkin, S. 1992. Conservationwith-development: an application of the concept in the Usambara Mountains, Tanzania. Transactions of the Institute of British Geographers NS, 17, 337-349.

Stowe, T. and Coulthard, N. 1990. The conservation of a Nigerian wetlands: the Hadejia-Nguru Wetland Project. RSPB Conservation Review, 4, 80-85.

Sule, A.R. 1993. Flood Extent, Depth and Volume from Satellite Data: The Hadejia-Nguru Wetlands, Northern Nigeria. Wetlands Research Unit, University College London.

Thomas, D.H.L. 1990. Progress report, October 1989-September 1990. Report to the HadejiaNguru Wetlands Conservation Project, Nguru, Nigeria.

Thomas, D.H.L. 1992a. Dagonna Experimental Fishpond Project: Progress Report. Hadejia-Nguru Wetlands Conservation Project, Nguru, Nigeria.

Thomas, D.H.L. 1992b. Beekeeping Demonstration 
Project: Progress Report. Hadejia-Nguru Wetlands Conservation Project, Nguru, Nigeria.

Thomas, D.H.L. 1994. Socio-economic and cultural factors in aquaculture development: a case study from Nigeria. Aquaculture, 119, 329-343.

Thomas, D.H.L. 1995a. Artisanal fishing and environmental change in a Nigerian floodplain wetland. Environmental Conservation, 22, 117-126.

Thomas, D.H.L. 1995b. Environment, socioeconomic change and sustainability in a Nigerian floodplain wetland. PhD thesis, Department of Geography, University of Cambridge.

Thomas, D.H.L. and Abubakar, K. 1992. Donkeys for Animal Traction: Progress Report. Hadejia-Nguru Wetlands Conservation Project, Nguru, Nigeria.
Thompson J.R. and Hollis, G.E. 1995. Hydrological modelling and the sustainable development of the Hadejia-Nguru Wetlands, Nigeria. Hydrological Sciences Journal, 40, 97-116.

Wells, M. and Brandon, K. 1992. People and Parks: Linking Protected Area Management With Local Communities. World Bank, Washington.

William M. Adams, Department of Geography, University of Cambridge, Cambridge CB2 3EN, UK.

David H. L. Thomas, Department of Geography, University of Edinburgh, Drummond Street, Edinburgh EH8 9XP, UK. 